\title{
The Facts About Termites and Mulch ${ }^{1}$
}

\section{Faith M. Oi and Marsha Wheeler ${ }^{2}$}

There have been many rumors swirling about the Internet concerning termites being spread throughout the country by large chain stores via bags of landscape mulch. In our opinion, the greater risk to structures is from termites already established in your yard as opposed to any termite stragglers that may be brought in on bags of mulch. Termites can be found in mulch, but their survival is poor and here is why: the ability of termites to survive the chipping process to create mulch is not good; additionally, once separated from the colony, their ability to survive further decreases. Finally, even when termites are found in mulch, mulch-fed termites suffer significantly lower survivorship (Long et al. 2001).

In terms of spreading invasive species like the Formosan subterranean termite, the greater problem is associated with the transport of large chunks of wood containing enough termites to sustain reproductive forms. For example, infested railroad ties used in landscape or salvaged timbers from razed structures are known to be associated with the spread of the Formosan subterranean termite (Forschler, et al. 2000).

This is not to say that termites are not found in association with mulch. We believe that mulch does contribute to termite infestations, but not because invasive species are spread with it. Mulch increases the ability of termites to survive where they are already established by keeping the soil moist and temperatures moderate. Mulch laid too thickly ( $>4-6$ inches) can also provide a "bridge" over the treated perimeter of a house, allowing termites to walk over from landscape to house and avoid contact with soil treated with termiticides.

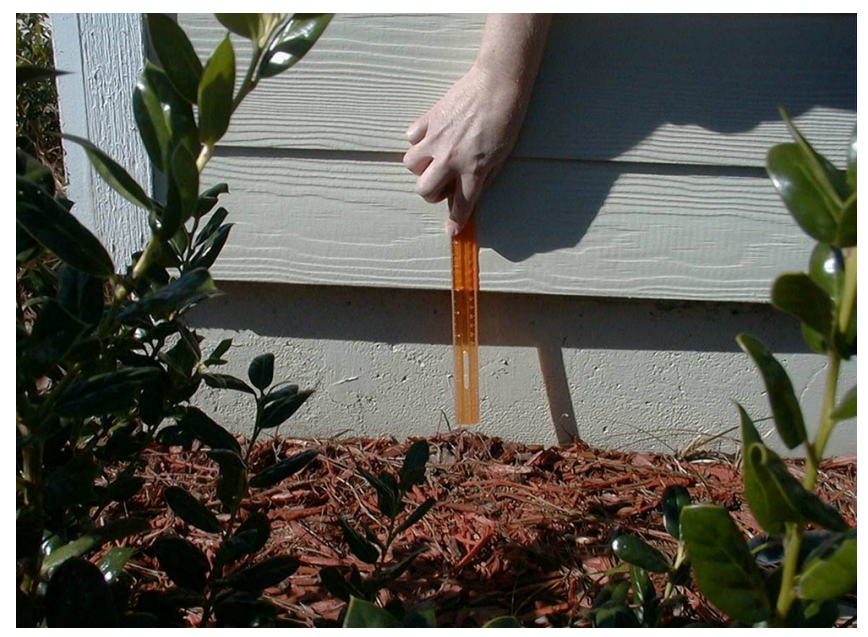

Figure 1. The current building code requires at least a 6 inch inspection gap, as shown in the picture above. The inspection gap between mulch and siding on the home will allow anyone to see if termites are building mud tubes into a structure.

1. This document is ENY-832 (IN651), one of a series of the Entomology and Nematology Department, Florida Cooperative Extension Service, Institute of Food and Agricultural Sciences, University of Florida. First published: March 2006. Please visit the EDIS Website at http://edis.ifas.ufl.edu.

2. Faith M. Oi, assistant extension scientist, and Marsha Wheeler, graduate research assistant, Entomology and Nematology Department, Institute of Food and Agricultural Sciences, University of Florida, Gainesville, FL 32611.

The Institute of Food and Agricultural Sciences (IFAS) is an Equal Opportunity Institution authorized to provide research, educational information and other services only to individuals and institutions that function with non-discrimination with respect to race, creed, color, religion, age, disability, sex, sexual orientation, marital status, national origin, political opinions or affiliations. U.S. Department of Agriculture, Cooperative Extension Service, University of Florida, IFAS, Florida A. \& M. University Cooperative Extension Program, and Boards of County Commissioners Cooperating. Larry Arrington, Dean 
Mulch is useful in keeping mud from splashing up against a house. If mulch is part of your landscape, we recommend a thin layer ( $<2$ inches) of mulch be placed within 12 inches of the foundation to allow the soil beneath to naturally dry. Desiccation is the termites worst enemy. Also avoid watering next to foundation walls.

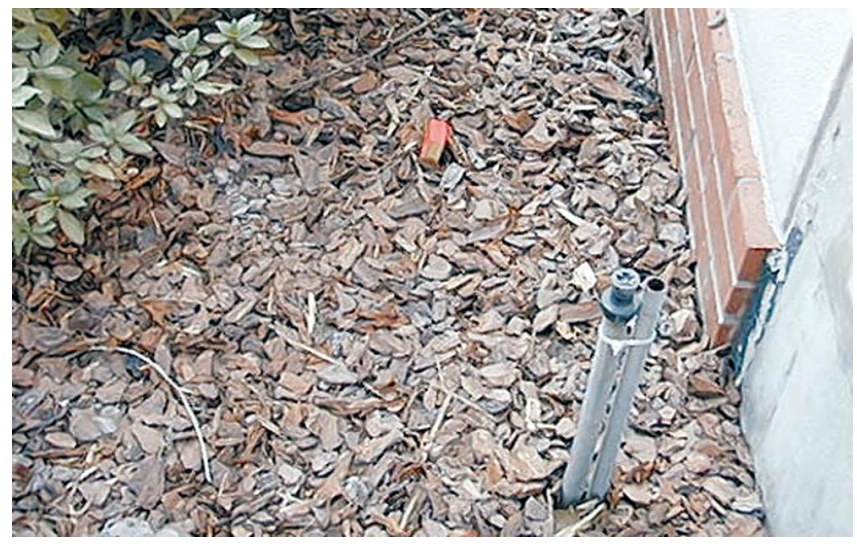

Figure 2. Mulch that is too thick and obscures an inspection space will result in what is termed a "conducive condition" in the pest control industry. Some termite contracts may become void with the presence of conducive conditions around a home. The irrigation head depicted here is in violation of the current building code. The Florida building code requires that irrigation be installed 1 foot or more away from a building sidewall. Irrigation heads that "water walls" is also considered a conducive condition.

Finally, maintain termite protection measures for your house. Protection measures most commonly include soil treatments, bait systems, or wood protection measures. (Remember to use a licensed and reputable pest control company.) Also, avoid wood to ground contact, including storing mulch off the ground.

The Louisiana Department of Agriculture has a quarantine order in place to prevent the spread of infested materials. To report a quarantine violation, call (225) 925-3763. The Department of Agriculture and Forestry's Web site, www.ldaf.state.la.us, and the LSU AgCenter's Web site, www.lsuagcenter.com, contain information about the quarantines, Formosan termites and debris disposal.

\section{References Cited}

Long et al. 2001. The effect of organic and inorganic landscape mulches on subterranean termite foraging activity. Entomol. 30(5): 832-836.
Forschler, B. T., J. Harron, and T. M. Jenkins. 2000. Case histories involving the Formosan subterranean termite in Atlanta, Georgia, USA (Isoptera: Rhinotermitidae). Sociobiology 36: 1-11. 